\title{
Lead - factors affecting its content in bone tissue
}

\author{
Barbara Brodziak-Dopierała $\bowtie$ \\ Medical University of Silesia in Katowice, Department of Toxicology and Bioanalysis, Jagiellońska 4, 41-200 Sosnowiec, Poland \\ ORCID: 0000-0002-3662-227X \\ $\triangle$ bbrodziak@sum.edu.pl
}

\begin{abstract}
Lead is an element whose presence in the environment results mainly from man's activities. It infiltrates the bodies of living organisms in many ways; in the human body, it has a multidirectional activity, causing anemia, kidney damage, mental retardation in children, genotoxicity, impaired immune function, damage to the nervous system and an inhibition of heme synthesis. Lead also affects bones; its concentrations there in contrast to soft tissues, are dependent on exposure and increase throughout ones lifespan. This element is the most
\end{abstract}

often studied and described metal in the bone tissue. The aim of this study was to determine the factors that influence the content of lead in the bone tissue and trace its content in this tissue based on literature data. The analysis of the collected literature showed an incredibly wide range of lead content in human bones was observed. This could be due to the different methods of determination (AAS, ICP-AES, K x-ray fluorescence) and the weight of the sample (dry or wet).

Keywords: lead; human bone; gender; age.

\section{INTRODUCTION}

Lead is a common pollutant, spanning across all elements of the environment. Sources of lead include, inter alia, steel, mining, haulage and the manufacture of batteries. Lead is absorbed into the body primarily through the respiratory system and digestive tract. Absorption from the gastrointestinal tract is significantly higher in children due to a more efficient transport of lead by transport proteins. Age is a critical variable for quantities of absorption. In adults, absorption from the diet amounts to $7-15 \%$, in infants and children, this may reach $40-53 \%[1,2]$.

About $90 \%$ of total lead in a human is accumulated in the bone tissue with a half-life of approx. 20 years $[3,4,5,6]$. In bone tissue, there are 2 independent pools collecting lead: stable - in the cortical bone, where the lead remains practically inactive, and labile - in the cancellous bone, which can relocate $[3,5,7]$. The half-life of lead in cancellous bone can range from several years in vertebrae, to 16 years in the calcaneus. In the cortical bone, the average half-life of lead amounts to 5-15 years but can last for 25 years $[3,7,8]$.

When lead is released from the bone, there is an increase in its concentration in the blood. This may occur during an increase in the turnover of bone (fractures and osteoporosis) and during pregnancy (lactation and menopause) [9]. The skeletal release of lead depends on several factors, for example, the nutrition and metabolism of calcium, and hormones such as 1.25-dihydroxycholecalciferol, estrogens, parathyroid hormone, calcitonin, growth hormones, prolactin and tyrosine.

Lead found in the body during bone turnover is incorporated into its mineral structure. The experiments carried out in vivo and in vitro allow for a conclusion to be drawn that lead directly or indirectly affects the function of bone cells. Lead can indirectly influence these functions by varying the level of certain hormones, especially 1.25-dihydroxyvitamin $D_{3}$, which is responsible for the regulation of bone cell function and parathyroid hormone in plasma $[10,11]$. Lead affects the function of bone cells by interfering with the ability of hormonal regulation of these cells [10]. It might diminish the production of osteocalcin proteins, which slows bone formation and the functional coupling of osteoblasts and osteoclasts. Therefore, a higher concentration of lead in the body means the bone formation process can be delayed [11]. Lead can also be transferred through the placenta into fetal tissues, reaching $80-90 \%$ of the concentration found in the mother. As such, lead accumulation in the body begins in fetal life $[12,13,14,15,16]$.

Lead has a multi-pronged effect on the human body, causing damage to the nervous system, inhibition of heme synthesis, anemia, kidney damage, mental retardation in children, genotoxicity and impaired immune function $[4,7,9,17,18,19,20]$.

Lead affects the humoral immune response by reducing the production of IgA and IgG, predisposing individuals to an increased incidence of infections and cancer. This effect was observed, inter alia, in the research involving steelworkers [17]. Lead which is released from the bones into the bloodstream is potentially an important source of exposure for the soft tissues. In addition, research on humans and animals shows the role of lead in the development of osteopenia [6]. Carmouche et al., in studies on mice, showed that exposure to lead can inhibit the healing of fractures. Exposure to lead leads to increased formation of cartilage, delayed maturation, and increased fibrous tissue during bone repair. In addition, lead causes degenerative changes within the cartilage of the knee joint in humans and animals [21]. 
Lead is incorporated into the bone during mineralization and remains there until the bone resorption by osteoclasts. It has a greater affinity to osteocalcin than calcium, increases the amount of the minerals bound by osteocalcin and interferes with calcium, signalization in cells competitive with calcium binding [22]. In addition, lead ions are able to move calcium ions through cation-exchange processes into hydroxyapatite, which may change the form of the crystal of hydroxyapatite, and thus affect its material properties (strength, ductility). Increased resorption of cortical bone during osteoarthritis may result in an increased release of lead into the circulation, as in osteoporosis [6].

The factors that determine the lead content of bone tissue include: type of bone tissue, gender, age, occupational exposure, pregnancy and lactation, concomitant disease, smoking.

\section{TYPE OF BONE TISSUE}

Lead content in human bone tissue has been the subject of many publications $[7,8,9,10,18,23,24,25,26,27,28,29,30$, 31]. However, very often there is fragmented information on different types of bones, studied with various analytical techniques or methods determined in vivo and as such, it is difficult to compare them to one another. The results are given based on the dry or wet weight - Table 1.

According to Barbosa et al. lead in the cancellous bone is more biologically active than lead in the cortical bone as the cancellous bone has a higher metabolic rate [32]. Todd et al. determined the content of lead in the tibial bone and found that it ranged 3.1-27.9 $\mu \mathrm{g} / \mathrm{g}$ dry weight. They went on to show a heterogeneous distribution of lead in the proximal and distal ends of the tibia and found that the content of lead in the tibia was greater on the surface than in the interior. As well as this, they found that the lead content in the tibia was lower in the proximal and distal tibia than it was in the central part $[26,33]$ These differences are explained by the fact that regions with a low lead content are regions with lower blood flow levels through the Haversian canals. This means that smaller amounts of lead are released into the bone matrix during construction. The cancellous bone has a greater surface area and an increased blood flow volume when compared to the cortical bone. In addition, the cancellous bone has more active osteons per gram of tissue, and these are responsible for the resorption of bone and tissue reconstruction [25].

Lanocha et al. determined the lead content in the femoral head tissue of humans inhabiting the north-west of Poland at $0.527 \mu \mathrm{g} / \mathrm{g}$ d.w. [34]. In the individual elements of the femoral head, people living in the same region had the following contents of lead: $0.527 \mu \mathrm{g} / \mathrm{g}$ d.w. in articular cartilage and cortical bone and $0.500 \mu \mathrm{g} / \mathrm{g}$ d.w. in the cancellous bone [35]. In residents of northern Poland, the lead content in the tissues of the femoral head was distributed as follows: cortical bone $0.60 \mathrm{mg} / \mathrm{kg}>$ cancellous bone $0.49 \mathrm{mg} / \mathrm{kg}>$ articular cartilage $0.41 \mathrm{mg} / \mathrm{kg}$ d.w. [27].
According to Jurkiewicz et al., the content of lead in the femoral head of inhabitants of an industrialized region of Poland (Upper Silesia), amounted to: cortical bone $3.05 \mu \mathrm{g} / \mathrm{g}>$ cancellous bone $2.56 \mu \mathrm{g} / \mathrm{g}>$ articular cartilage $3.53 \mu \mathrm{g} / \mathrm{g}$ d.w. [28]. Brodziak-Dopierała et al., studied the content of lead in the tissues of the femoral head of people residing in Upper Silesia and found the following levels: cancellous bone $1.32 \mu \mathrm{g} / \mathrm{g}>$ articular cartilage $1.25 \mu \mathrm{g} / \mathrm{g}>$ cortical bone $1.05 \mu \mathrm{g} / \mathrm{g}$, while in the cancellous bone of the intertrochanteric region $-0.75 \mu \mathrm{g} / \mathrm{g}$ and joint capsule - $0.19 \mu \mathrm{g} / \mathrm{g}$ d.w. [18].

Garcia et al. analyzed the content of lead in human ribs and found that this was approx. 6 times greater than the content in the brain, kidneys and lungs. The average content was $1.79 \mu \mathrm{g} / \mathrm{g}$ wet weight and the scope of change: $0.28-3.50 \mu \mathrm{g} / \mathrm{g}$ w.w. [23]. In a study conducted by Mari et al., the average content of lead in the bones was $1.39 \mu \mathrm{g} / \mathrm{g}$ w.w. and the scope of change ranged between 0.025-4.88 $\mu \mathrm{g} / \mathrm{g}$ w.w. Comparing the lead content in bones to content in other tissues such as the brain, kidney, lung, and liver showed that content in bones was the highest. The type of bones which were used in these studies was not specified [37].

The lead content in the ribs of people living in non-industrialized areas of central Russia was $1.42 \mu \mathrm{g} / \mathrm{g}$ w.w. [38]. The average content of lead in the bone tissue of people living in highly industrialized areas of Taiwan was determined by Kuo et al. at $7.1 \mu \mathrm{g} / \mathrm{g}$, and the scope of change ranged 3.73-19.6 $\mu \mathrm{g} / \mathrm{g}$ w.w. [24].

For people living in Upper Silesia, the content of lead in the sternum determined by Baranowska et al. was $57.55 \mu \mathrm{g} / \mathrm{g}$ w.w. [39].

Mergen et al. identified levels of lead in the bone tissue of the ribs of people from Turkey and found the average content was $0.405 \mu \mathrm{g} / \mathrm{g}$ [40]. In the ribs of elderly Japanese people (average age 81.5 years) the content of lead was $6.85 \mu \mathrm{g} / \mathrm{g}$ d.w. [25]. In the ribs of citizens of Gdańsk (northern Poland), the content of lead was $3 \mu \mathrm{g} / \mathrm{g} \mathrm{d.w.} \mathrm{[36].} \mathrm{The} \mathrm{lead} \mathrm{content} \mathrm{in} \mathrm{the} \mathrm{ribs}$ of people living in non-industrialized areas of central Russia was $1.42 \mu \mathrm{g} / \mathrm{g}$ w.w. [38].

Levels of lead were tested using the fluorescence method (K x-ray fluorescence) on women living in the region of Boston in the USA and a higher content of lead was found in the kneecap $(17 \mu \mathrm{g} / \mathrm{g})$ than in the tibia $(13 \mu \mathrm{g} / \mathrm{g})$ [41].

\section{GENDER}

Exposure to lead is associated with a reduction in bone mass in postmenopausal women [42].

Lanocha et al. showed differences in the content of lead in articular cartilage and cortical bone, taking into account the sex of the patients, with determinations made by the ICP-EAS method. Statistically significantly higher lead content has been found in the cartilage and cortical bones of men (0.644 mg/ $\mathrm{kg}$ d.w.) than in women (0.463 mg/kg d.w.). In the same study, there was no statistically significant difference in lead levels in the cancellous bone between women $(0.506 \mathrm{mg} / \mathrm{kg} \mathrm{d.w.)} \mathrm{and}$ in men (0.490 mg/kg d.w.) [35]. 
TABLE 1. Knowledge of patient rights

\begin{tabular}{|c|c|c|c|c|}
\hline Type of bone & Concentrations & Country & Methods & References \\
\hline Tibial & $54 \mu \mathrm{g} / \mathrm{g}$ d.w. & Taiwan & K-shell XRF & Todd et al. [26], \\
\hline Femoral head & $0.527 \mu \mathrm{g} / \mathrm{g}$ d.w. & Poland & ICP-EAS & Lanocha et al. [34] \\
\hline Ribs & $6.85 \mu \mathrm{g} / \mathrm{g}$ d.w & Japan & ICP-AES/AAS & Yoshinaga et al. [25] \\
\hline Ribs & $3 \mu \mathrm{g} / \mathrm{g}$ d.w. & Poland & AAS & Hać et al. [36] \\
\hline Femoral head & $3.05 \mu \mathrm{g} / \mathrm{g}$ d.w. & Poland & GFAAS & Jurkiewicz et al. [28] \\
\hline Femoral head & $1.21 \mu \mathrm{g} / \mathrm{g}$ d.w. & Poland & AAS & Brodziak-Dopierała et al. [18] \\
\hline Ribs & 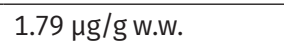 & Spain & ICP-MS & Garcia et al. [23] \\
\hline Bone & 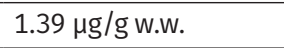 & Spain & ICP-MS & Mari et al. [37] \\
\hline Ribs & $1.42 \mu g / g$ w.w. & Russia & ICP-MS & Zaichick [38] \\
\hline Bone & 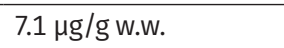 & Taiwan & ICP-AES & Kuo et al. [24] \\
\hline Sternum bones & $57.55 \mu \mathrm{g} / \mathrm{g}$ w.w. & Poland & GFAAS & Baranowska et al. [39] \\
\hline Ribs & $0.405 \mu \mathrm{g} / \mathrm{g}$ & Turkey & AAS & Mergen et al. [40] \\
\hline Tibia Kneecap & $13 \mu \mathrm{g} / \mathrm{g}, 17 \mu \mathrm{g} / \mathrm{g}$ & USA & K x-ray fluorescence & Korrick et al. [41] \\
\hline
\end{tabular}

In the ribs of Japanese people, Yoshinaga et al. noted statistically significant differences $(p<0.05)$ in the content of lead in the bones between women and men; content among men was higher (7.57 $\mu \mathrm{g} / \mathrm{g}$ d.w.) than women (5.34 $\mu \mathrm{g} / \mathrm{g}$ d.w.) [25]. A comparison of the content of lead in the femoral head of men and women living in northern Poland revealed no statistically significant differences. In women, the lead content in various parts of the femoral head was, $0.41 \mu \mathrm{g} / \mathrm{g}$ d.w. in articular cartilage; $0.49 \mu \mathrm{g} / \mathrm{g}$ d.w. in cortical bones and $0.47 \mu \mathrm{g} / \mathrm{g}$ d.w. in cancellous bones; in men the lead content in various parts of the femoral head was more varied: $0.40 \mu \mathrm{g} / \mathrm{g}$ d.w. in articular cartilage; $0.83 \mu \mathrm{g} / \mathrm{g}$ d.w. in the cortical bone and $0.49 \mu \mathrm{g} / \mathrm{g}$ d.w. in the cancellous bone [27].

Jurkiewicz et al. determined the lead content in the femoral head of people in Upper Silesia, Poland which is an area rich with industry. Significant differences in the content of lead levels in the cortical and cancellous bone were found. A higher lead content occurred in all parts of the femoral head in men when compared with women. In women, the lead content was: cortical bone 2.55 > cancellous bone 2.02 > articular cartilage 3.06, while in men, it was: 4.35, 4.12 and 5.01 ( $\mu \mathrm{g} / \mathrm{g} \mathrm{d.w.),} \mathrm{respectively} \mathrm{[28].}$

In studies concerning selected tissues of the hip, statistically significant differences $(p=0.005)$ in lead content between men and women only occurred for articular cartilage of the femoral head. Among women, the content was $3.28 \mu \mathrm{g} / \mathrm{g}$ d.w. and among men, $1.98 \mu \mathrm{g} / \mathrm{g}$ d.w. Statistically significant differences did not occur in other parts of the hip joint: joint capsule, cancellous bone from the intertrochanteric region, cortical bone and cancellous femoral head [18].

Garcia et al. determined the content of lead in the human ribs and did not find any significant differences between men and women. In men the lead content was slightly higher (2.56 $\mu \mathrm{g} / \mathrm{g}$ d.w.) than in women (2.16 $\mu \mathrm{g} / \mathrm{g}$ d.w.) [23]. Similarly, in research conducted by Mari et al., there were no differences in the content of lead in the bones of men and women [37].

According to Beneš et al., in the bones of people living in the Czech Republic, the content of lead was at level 4 and within gender, there were no statistically significant differences [43]. In the bone tissue of people from Turkey there were statistically significant differences $(\mathrm{p}<0.05)$ in the content of lead among men and women, in women lead content was $0.712 \mu \mathrm{g} / \mathrm{g}$ whereas in men, it was $0.320 \mu \mathrm{g} / \mathrm{g}$ [40].

In the bone tissue of the ribs, Zaichick did not observe any statistically significant differences in the content of lead in men (1.36 mg/kg w.w.) and women (1.46 mg/kg w.w.) [38]. In the bones of people living in Taiwan the content of lead among men was $6.77 \mu \mathrm{g} / \mathrm{g}$ w.w. and was lower than lead content in women $-7.63 \mu \mathrm{g} / \mathrm{g}$ w.w. [24]. Todd et al. indicated that the content of lead in the tibia of people who were exposed to lead at work showed no statistically significant differences based on sex [26]. The lead content in the ribs of women and men living in the vicinity of hazardous waste incineration plants in Tarragona, Spain also did not differ significantly. In men, it was only slightly higher $(2.31 \mu \mathrm{g} / \mathrm{g}$ w.w. $)$ when compared with women (1.42 $\mu \mathrm{g} / \mathrm{g}$ w.w.) [23].

\section{AGE}

Accumulation of lead in various parts of the skeleton is diverse and determined by the type of bone. Initially, lead in the skeleton is mainly deposited in the spongy bone and cortical bone. The study of lead distribution revealed that it is deposited in bones with a greater metabolic activity [44].

Wittmers et al. examined the contents of lead in 5 types of bones: the tibia, pelvis, rib, vertebrae and skull in 6 different age groups. Up to the age of 20 , the highest content of lead was in the vertebrae and the skull bones, while the lowest was in the tibia and the pelvis. For those who were over 35 years of age, the amount of lead was higher in the tibia [45].

In our own research, the studied population was divided into 3 age groups: $50-60$ years, $61-70$ years and $71-80$ years. The lead content clearly increased with age in the articular cartilage and joint capsules, inter alia. Significant differences related to the levels of lead content in articular cartilage were found between the age groups 50-60 and 71-80 years. In cancellous bones, the changes in lead content with age were insignificant and all 3 
age groups showed similar levels which amounted to approx. $1.8 \mu \mathrm{g} / \mathrm{g}$ d.w. In the cortical bone, the highest content of lead was found in those who were 50-60, and in the cancellous bone of the intertrochanteric region, in the group aged 61-70 [18].

The lead content in the ribs of people living in non-industrialized areas of central Russia, determined by Zaichick, did not show statistically significant differences with regard to age. In the age group 15-35 years, the average content was $1.34 \mu \mathrm{g} / \mathrm{g}$ w.w. and in the group of 36-55 years, $1.46 \mu \mathrm{g} / \mathrm{g}$ w.w. [38]. Kuo et al. observed that the content of lead in the bones of people from industrialized areas of Taiwan increased with age. In patients up to 40 years of age, lead levels were $4.51 \mu \mathrm{g} / \mathrm{g}$, followed by $6.13 \mu \mathrm{g} / \mathrm{g}$ in those aged between $41-60$ years, $7.62 \mu \mathrm{g} / \mathrm{g}$ in those aged between 61-80 and 9.36 $\mu \mathrm{g} / \mathrm{g}$ w.w. in patients over 80 years of age [24].

In the femoral and pelvic bone of people living in Bavaria, the content of lead increased until middle age, wherein it plateaued, and then decreased with age [46]. Garcia et al. confirmed that the accumulation of lead in the human ribs increased with age $(r=0.31, p=0.007)$ [23]. According to Korrick et al. in a group of women, the lead content in the tibia increased with age. In the age group of 46-54 years, it was $10.5 \mu \mathrm{g} / \mathrm{g}$, and in the group of 65-74 year olds it was $16.4 \mu \mathrm{g} / \mathrm{g}(\mathrm{p} \leq 0.01)$. The content of lead in the kneecap also increased with age from 14.9 to 19.8 $\mu \mathrm{g} / \mathrm{g}(\mathrm{p} \leq 0.01)[41]$.

\section{OCCUPATIONAL EXPOSURE}

Olsson et al. determined the content of lead in the bones of active and retired employees of car battery recycling plants. The study was conducted in Germany and Sweden. The period of employment for German workers was approx. 3 times longer than that of the Swedes. The median amount of lead levels in the German population was $71 \mu \mathrm{g} / \mathrm{g}$ for active employees, and $150 \mu \mathrm{g} / \mathrm{g}$ for retirees. For the Swedes, it was 23 and $55 \mu \mathrm{g} / \mathrm{g}$, respectively. These results confirmed that employment which is associated with constant exposure to lead compounds effects the content of lead in bone tissue [47]. It was observed that a single measurement for lead in the blood of active employees does not measure the level of lead in the skeleton, whereas the same test in retired employees is more reliable.

Todd et al. found that the contents of lead in the tibia among people exposed to lead at work averaged to $54.0 \mu \mathrm{g} / \mathrm{g}$ d.w. [26], while Morrow et al. indicated that this was $67.78 \mu \mathrm{g} / \mathrm{g}$. Some authors observed a correlation between lead content in blood and bones, especially in those aged between 50-59 years $(\mathrm{r}=$ 0.49) and 60-76 years $(r=0.75)$ [48].

Studies have shown that retired employees exposed professionally to lead in the past have a higher content of lead in the tibia and kneecap in comparison to professionally active people in the same field. The contents of lead in the tibia and kneecap in professionally active people was 5.5-6.5 $\mu \mathrm{g} / \mathrm{g}$, while in retirees, 11.3-20.5 $\mu \mathrm{g} / \mathrm{g}$ respectively [49].

Khalil et al. have identified the content of lead in the bones of people exposed professionally to lead as $57 \mu \mathrm{g} / \mathrm{g}$ and in those not exposed as $12 \mu \mathrm{g} / \mathrm{g}(\mathrm{p}<0.001)$ [50]. Gerhardsson et al. observed that levels of lead in the investigated bones were statistically significantly higher among active employees $(p<0.001)$ and retirees $(p \leq 0.003)$ exposed to lead at work when compared with a control group. Statistically significant differences were found in the content of lead in the bones between active and retired workers occupationally exposed to lead. The highest content of lead was observed among active workers finger bones (median $106 \mu \mathrm{g} / \mathrm{g}$ d.w.) and then in the vertebrae (85 $\mu \mathrm{g} / \mathrm{g})$, iliac crests (83 $\mu \mathrm{g} / \mathrm{g})$, sternum $(74 \mu \mathrm{g} / \mathrm{g})$ and ribs $(70 \mu \mathrm{g} / \mathrm{g})$. The lowest content of lead occurred in the temporal bone $(59 \mu \mathrm{g} / \mathrm{g})$ and femur $(56 \mu \mathrm{g} / \mathrm{g})$. Similarly, the content of lead among retired employees was mostly found in finger bones - $97 \mu \mathrm{g} / \mathrm{g}$ d.w. Lead content in the bones of retired employees was smaller in comparison to active employees in the case of finger bones, vertebrae, iliac crests, sternum and ribs, but higher in the femur and temporal bone [3].

The lead content in the ribs of people living near a hazardous waste incineration plant in Tarragona in Spain was 3.99 $\mu \mathrm{g} / \mathrm{g}$ in 1998 and $2.11 \mu \mathrm{g} / \mathrm{g}$ w.w. in 2003 [44]. The level of lead in the bones of these individuals increased with age, in individuals up to 35 years of age, lead content was $0.36 \mu \mathrm{g} / \mathrm{g}$, between $35-65$ years of age $-1.79 \mu \mathrm{g} / \mathrm{g}$, and over 60 years old -3.20 $\mu \mathrm{g} / \mathrm{g}$ w.w. Differences between the age groups were statistically significant [44].

Retired employees of steelworks had the highest content of lead in the bones of the fingers with a median of $55 \mu \mathrm{g} / \mathrm{g}$ w.w., active employees of steelworks showed $23 \mu \mathrm{g} / \mathrm{g}$ w.w. and the reference group, comprising of staff not occupationally exposed to lead, had $3 \mu \mathrm{g} / \mathrm{g}$ w.w. A strong positive correlation was observed between the content of lead in the bones and blood among active ( $\mathrm{rs}=0.73, \mathrm{p}<0.001)$ and retired steel workers ( $\mathrm{rs}=0.71, \mathrm{p}=0.001$ ) [8]. The correlations between the content of lead in the bones and period of employment were at a similar level. It is estimated that the biological half-life of lead in the bones of active workers occupationally exposed to lead was 5.2 years [8].

\section{PREGNANCY AND LACTATION}

Lead easily crosses the placenta by passive diffusion. At the end of the 1st trimester, lead was detected in the brains of the fetus. An increased level of lead during pregnancy is associated with adverse effects, such as gestational hypertension, miscarriage, low birth weight and neurodevelopmental disorders [51]. The offspring of mothers occupationally exposed to lead have an increased risk of low birth weight compared with children of women not exposed to lead [52].

During pregnancy, bone resorption, rather than the absorption of nutrients, has the greatest impact on changes in the levels of lead in blood [14]. Resorption of trabecular and cortical bone occurs during different times in pregnancy [13]. In early pregnancy, only the cancellous bone (presumably with low lead content) is subject to resorption, the concentration of lead in blood decreases more than expected due to the dilution 
of blood. In the later stages of pregnancy, resorption mainly occurs in the cortical bone which has a higher lead content and leads to an increase in lead concentration in the blood. During lactation, resorption affects the whole skeleton and increases the concentration of lead in the blood of breast-feeding mothers. Lead levels in blood decrease with the number of pregnancies a woman has, suggesting that the greatest risk arising from the toxicity of lead is connected with the 1st pregnancy [13].

Lead stored in the bones does not pose a serious threat to the health of the majority of pregnant women and their children. However, this is not always the case. In both the United States and in other countries, there are instances where a woman was exposed to lead during childhood and accumulated large stocks in the bones. The most critical period for the mother is the time after birth as the concentration of lead in the blood increases during breastfeeding while for the fetus, the last weeks of pregnancy are the most critical time [51].

High levels of lead in the mother's trabecular bone are an independent risk factor for the development of mental disorders in children under 24 months of age. This occurs by launching a pot of lead from the bones of mothers [53].

Tellez-Rojo et al. determined lead levels among lactating women [54]. The content in the tibia was $10.6 \mu \mathrm{g} / \mathrm{g}$ and $15.3 \mu \mathrm{g} / \mathrm{g}$ in the kneecap. After considering the lead content in the bones and any environmental exposure, women who breast-fed their children exclusively had an increase in lead levels in blood by $1.4 \mu \mathrm{g} / \mathrm{dL}$, while among women who practiced mixed feeding - by $1.0 \mu \mathrm{g} / \mathrm{dL}$, compared to women who had not lactated [54]

A relationship between the number of times a woman gives birth and the content of lead in the tibia was also found; among women not giving birth, the content was $21.3 \mu \mathrm{g} / \mathrm{g}$, while among women giving birth 4 times or more $-12.8 \mu \mathrm{g} / \mathrm{g}(\mathrm{p} \leq 0.01)$. In the case of lactation, statistically significant differences occurred in both the tibia $(\mathrm{p} \leq 0.01)$ and patella $(\mathrm{p} \leq 0.15)$. In non-lactating women, the content in the tibia was $21.3 \mu \mathrm{g} / \mathrm{g}$ and in women who were lactating for between 9-48 months -11.7 $\mu \mathrm{g} / \mathrm{g}$, in the kneecap, these figures were $21.6 \mu \mathrm{g} / \mathrm{g}$ and 16.2 $\mu \mathrm{g} / \mathrm{g}$ respectively [42].

\section{CONCOMITANT DISEASE}

Information on lead content in various diseases are very rudimentary. Lead content in the ribs of Japanese people was determined in comparison to patients with malignant tumors, the content of the control group was $5.40 \mu \mathrm{g} / \mathrm{g}$ d.w. $(\mathrm{p}<0.05)$ and $9.28 \mu \mathrm{g} / \mathrm{g}$ for those with cancer [25].

Kuo et al. determined the content of lead in the bone tissue of patients with various diseases: femoral neck fractures, ischemic necrosis of the femoral head, osteoarthritis of the hip or knee, and others. There was no significant difference in lead content between the 4 groups. The largest lead content was observed in patients with fractures of the femoral neck at $8.26 \mu \mathrm{g} / \mathrm{g}$ and the smallest - in patients with ischemic necrosis of the femoral head $-5.73 \mu \mathrm{g} / \mathrm{g}$ w.w. [24].
In the case of patients with osteoporosis and those without osteoporosis, documented using the Mann-Whitney U test, no statistically significant differences were found in lead content between the 2 groups [55].

\section{SMOKING}

Garcia et al. showed significant differences in the case of lead content in the ribs of smokers and non-smokers [23]. Among smokers lead content was $2.11 \mu \mathrm{g} / \mathrm{g}$ and among non-smokers $1.58 \mu \mathrm{g} / \mathrm{g}$. Kuo et al. observed no correlation between the content of lead in the ribs and smoking [24].

In the bones of women, there were also no statistically significant differences observed between the content of lead and cigarette smoking [41].

The lead content in the articular cartilage and cortical bones of non-smokers was $0.467 \mu \mathrm{g} / \mathrm{g}$ while in smokers this was 0.555 $\mu \mathrm{g} / \mathrm{g}$ d.w. [55]. In the cancellous bone in non-smokers, the lead content was higher $(0.529 \mu \mathrm{g} / \mathrm{g}$ d.w.) than in smokers $(0.473 \mu \mathrm{g} / \mathrm{g}$ d.w.). Lead content in articular cartilage and cortical bone in smokers was $16 \%$ higher than in non-smokers. No statistically significant correlation between the concentrations of lead in both types of bone material and the number of cigarettes smoked were found. Only lead content in articular cartilage and the cortical bone showed a weak association with the number of cigarettes smoked $(r=0.321, p<0.1)$ [54].

\section{CONCLUSION}

Based on the analysis of the collected literature, a very wide range of lead content $(0.32-7.7 \mu \mathrm{g} / \mathrm{g})$ in human bones was observed. This is probably due to differences in determination methods (AAS, ICP-AES, K x-ray fluorescence) and the weight of the sample (dry or wet).

On the basis of the collected literature there is no clear information on the differences in the prevalence of lead in the bones of men and women. Frequently, authors reported no statistically significant differences in the content of lead in the bones of men and women.

Often, studies emit information on what bones were investigated and what kind of bone tissue (cortical, cancellous) was studied. In the case of research on Polish territory, the bones that are most frequently studied in relation to lead content, are the ribs and the head of the femur.

Most authors reported that lead content in bones increases with age. Occupational exposure to lead increases the content of lead in bone tissue. During pregnancy and lactation, lead content reduces in bones and increases in blood. As the mother has more pregnancies, the lead content in bones is reduced. This means that, for the fetus, the highest exposure to lead occurs during the mothers 1st pregnancy and lactation. In most studies, there were no significant correlations between the content of lead in the bones of smokers and non-smokers. 
Despite a rich literature on the content of lead in bone tissue, there is scarce information about lead content in relation to various diseases. As such, no general conclusions can be drawn.

\section{REFERENCES}

1. National Environmental Policy Institute. Assessing the bioavailability of metals in soil for use in human health risk assessments. Bioavailability Policy Project Phase II: Metals Task Force Report. Washington, DC: NEPI; 2000.

2. Robson M. Methodologies for assessing exposures to metals: human host factors. Ecotoxicol Environ Saf 2003;56(1):104-9.

3. Gerhardsson L, Akantis A, Lundstrom NG, Nordberg GF, Schütz A, Skerfving $S$. Lead concentrations in cortical and trabecular bones in deceased smelter workers. J Trace Elem Med Biol 2005;19(2-3):209-15.

4. Skerfving S, Nilsson U, Schütz A, Gerhardsson L. Biological monitoring of inorganic lead. Scand J Work Environ Health 1993;19 Suppl 1:59-64.

5. Gerhardsson L, Attewell R, Chettle DR, Englyst V, Lundström NG, Nordberg GF, et al. In vivo measurements of lead in bone in long-term exposed lead smelter workers. Arch Environ Health 1993;48(3):147-56.

6. Zoeger N, Roschger P, Hofstaetter JG, Jokubonis C, Pepponi G, Falkenberg G, et al. Lead accumulation in tidemark of articular cartilage. Osteoarthritis Cartilage 2006;14(9):906-13.

7. Bergdahl IA, Strömberg U, Gerhardsson L, Chettle DR, Skerfving S. Lead concentrations in tibial and calcaneal bone in relation to the history of occupational lead exposure. Scand J Work Environ Health 1998;24(1):38-45.

8. Börjesson J, Mattsson S, Strömberg U, Gerhardsson L, Schütz A, Skerfving $S$. Lead in fingerbone: a tool for retrospective exposure assessment. Arch Environ Health 1997;52(2):104-12.

9. Berglund M, Akesson A, Bjellerup P, Vahter M. Metal-bone interactions. Toxicol Lett 2000;112-113:219-25.

10. Hu H, Wu MT, Cheng Y, Sparrow D, Weiss S, Kelsey K. The $\delta$-aminolevulinic acid dehydratase (ALAD) polymorphism and bone and blood lead levels in community-exposed men: the normative aging study. Environ Health Perspect 2001;109(8):827-32.

11. Behinaein S, Chettle DR, Egden LM, McNeill FE, Norman G, Richard N, et al. The estimation of the rates of lead exchange between body compartments of smelter employees. Environ Sci Process Impacts 2014;16(7):1705-15.

12. Rothenberg SJ, Kondrashov V, Manalo M, Jiang J, Cuellar R, Garcia M, et al. Increases in hypertension and blood pressure during pregnancy with increased bone lead levels. Am J Epidemiol 2002;156(12):1079-87.

13. Rothenberg SJ, Khan F, Manalo M, Jiang J, Cuellar R, Rejes S, et al. Maternal bone lead contribution to blood lead during and after pregnancy. Environ Res 2000;82(1):81-90.

14. Manton WI, Angle CR, Stanek KL, Kuntzelaman D, Reese YR, Kuehnemann TJ. Release of lead from bone in pregnancy and lactation. Environ Res 2003;92(2):139-51.

15. Markowitz ME, Shen XM. Assessment of bone lead during pregnancy: a pilot study. Environ Res 2001;85(2):83-9.

16. Wasserman GA, Liu X, Pine DS, Graziano JH. Contribution of maternal smoking during pregnancy and lead exposure to early child behavior problems. Neurotoxicol Teratol 2001;23(1):13-21.

17. Skoczyńska A, Poręba R, Sieradzki A, Andrzejak R, Sieradzka U. Wpływ ołowiu i kadmu na funkcje układu immunologicznego. Med Pr 2002;53(3):259-64.

18. Brodziak-Dopierała B, Kowol J, Kwapuliński J, Kusz D, Cieliński Ł. Lead and calcium content in the human hip joint. Biol Trace Elem Res 2011;144(1-3):6-16.

19. Nordberg GF, Fowler BA, Nordberg M, Friberg LT. Handbook on the toxicology of metals. London: Elsevier; 2008.

20. Barry V, Todd AC, Steenland K. Bone lead associations with blood lead, kidney function and blood pressure among US, lead-exposed workers in a surveillance programme. Occup Environ Med 2019;76(5):349-54.

21. Carmouche JJ, Puzas JE, Zhang X, Tiyapatanaputi P, Cory-Slechta DA, Gelein R, et al. Lead exposure inhibits fracture healing and is associated with increased chondrogenesis, delay in cartilage mineralization, and a decrease in osteoprogenitor frequency. Environ Health Perspect 2005;113(6):749-55.
22. Pemmer B, Roschger A, Wastl A, Hofstaetter JG, Wobrauschek P, Simon R, et al. Spatial distribution of the trace elements zinc, strontium and lead in human bone tissue. Bone 2013;57(1):184-93.

23. Garcia F, Ortega A, Domingo JL, Corbella J. Accumulation of metals in autopsy tissues of subjects living in Tarragona County, Spain. J Environ Sci Health A Tox Hazard Subst Environ Eng 2001;36(9):1767-86.

24. Kuo HW, Kuo SM, Chou CH, Lee TC. Determination of 14 elements in Taiwanese bones. Sci Total Environ 2000;255(1-3):45-54.

25. Yoshinaga J, Suzuki T, Morita M, Hayakawa M. Trace elements in ribs of elderly people and elemental variation in the presence of chronic diseases. Sci Total Environ 1995;162(2-3):239-52.

26. Todd AC, Ginde NR, Ho CK, Luo JC, Tolman J, Tsai JL, et al. A pilot evaluation of tibia lead concentrations in Taiwan. Am J Ind Med 2001;40(2):127-32.

27. Łanocha N, Kalisińska E, Kosik-Bogacka D, Budis H, Sokołowski S, Bohatyrewicz A. Comparison of concentrations of lead and cadmium in various parts of the femur head in patients after arthroplasty of the hip joint in Northwest Poland. Biomed Environ Sci 2012;25(5):577-82.

28. Jurkiewicz A, Wiechuła D, Nowak R, Loska K. Lead content in the femoral heads of inhabitants of Silesia (Poland). J Trace Elem Med Biol 2005;19(2-3):165-70.

29. Specht AJ, Lin Y, Xu J, Weisskopf M, Nie LH. Bone lead levels in an environmentally exposed elderly population in Shanghai, China. Sci Total Environ 2018;626:96-8.

30. Specht AJ, Dickerson AS, Weisskopf MG. Comparison of bone lead measured via portable $\mathrm{x}$-ray fluorescence across and within bones. Environ Res 2019;172:273-8.

31. Wong AKO, Beattie KA, Bhargava A, Cheung M, Webber CE, Chettle DR, et al. Bone lead $(\mathrm{Pb})$ content at the tibia is associated with thinner distal tibia cortices and lower volumetric bone density in postmenopausal women. Bone 2015;79:58-64.

32. Barbosa F Jr, Tanus-Santos JE, Gerlach RF, Parsons PJ. A critical review of biomarkers used for monitoring human exposure to lead: advantages, limitations, and future needs. Environ Health Perspect 2005;113(12):1669-74.

33. Todd AC, Parsons PJ, Tang S, Moshier EL. Individual variability in human tibia lead concentration. Environ Health Perspect 2001;109(11):1139-43.

34. Lanocha N, Kalisinska E, Kosik-Bogacka DI, Budis H, Sokolowski S, Bohatyrewicz A. Comparison of metal concentrations in bones of longliving mammals. Biol Trace Elem Res 2013;152(2):195-203.

35. Lanocha N, Kalisinska E, Kosik-Bogacka DI, Budis H, Sokolowski S, Bohatyrewicz A. Concentrations of trace elements in bones of the hip joint from patients after hip replacement surgery. J Trace Elem Med Biol 2012;26(1):20-5.

36. Hać E, Czarnowski W, Gos T, Krechniak J. Lead and fluoride content in human bone and hair in the Gdańsk region. Sci Total Environ 1997;206(23):249-54.

37. Mari M, Nadal M, Schuhmacher M, Barbería E, García F, Domingo JL. Human exposure to metals: levels in autopsy tissues of individuals living near a hazardous waste incinerator. Biol Trace Elem Res 2014;159(1-3):15-21.

38. Zaichick V. Data for the Reference Man: skeleton content of chemical elements. Radiat Environ Biophys 2013;52:65-85.

39. Baranowska I, Czernicki K, Aleksandrowicz R. The analysis of lead, cadmium, zinc, copper and nickel content in human bones from the Upper Silesian industrial district. Sci Total Environ 1995;159(2-3):155-62.

40. Mergen G, Kayaalti Z, Söylemezoglu T. Cadmium, lead, zinc and copper levels and MT2A polymorphism in autopsy bone tissues. Toxicol Lett 2008;180S:S191.

41. Korrick SA, Schwartz J, Tsaih SW, Hunter DJ, Aro A, Rosner B, et al. Correlates of bone and blood lead levels among middle-aged and elderly women. Am J Epidemiol 2002;156(4):335-43.

42. Pollack AZ, Mumford SL, Wactawski-Wende J, Yeung E, Mendola P, Mattison DR, et al. Bone mineral density and blood metals in premenopausal women. Environ Res 2013;120:76-81.

43. Beneš B, Jakubec K, Šmíd J, Spěváčková V. Determination of thirty-two elements in human autopsy tissue. Biol Trace Elem Res 2000;75(1-3):195-203.

44. Bocio A, Nadal M, Garcia F, Domingo JL. Monitoring metals in the population living in the vicinity of a hazardous waste incinerator: concentrations in autopsy tissues. Biol Trace Elem Res 2005;106(1):41-50.

45. Wittmers LE, Aufderheide AC, Wallgren J, Rapp G, Alich A. Lead in bone IV. Distribution of lead in the human skeleton. Arch Environ Health 1988;43(6):381-91. 
46. Drash GA, Böhm J, Baur C. Lead in human bones. Investigations on an occupationally non-exposed population in southern Bavaria (F.R.G.) I. Adults. Sci Total Environ 1987;64(3):303-15.

47. Olsson M, Gerhardsson L, Jensen A, Börjesson J, Schütz A, Mattsson S, et al Lead accumulation in highly exposed smelter workers. Ann NY Acad Sci 2000;904:280-3.

48. Morrow LA, Needleman HL, McFarland C, Metheny K, Tobin M. Past occupational exposure to lead: association between current blood lead and bone lead. Arch Environ Occup Health 2007;62(4):183-6.

49. Elmarsafawy SF, Tsaih SW, Korrick S, Dickey JH, Sparrow D, Aro A, et al. Occupational determinants of bone and blood lead levels in middle aged and elderly men from the general community: the Normative Aging Study. Am J Ind Med 2002;42(1):38-49.

50. Khalil N, Morrow LA, Needleman H, Talbott EO, Wilson JW, Cauley JA. Association of cumulative lead and neurocognitive function in an occupational cohort. Neuropsychology 2009;23(1):10-9.
51. Committee on Obstetric Practice. Committee opinion No. 533: lead screening during pregnancy and lactation. Obstet Gynecol 2012;120(2 Pt 1):416-20.

52. Irgens A, Krüger K, Skorve AH, Irgens LM. Reproductive outcome in offspring of parents occupationally exposed to lead in Norway. Am J Ind Med 1998;34(5):431-7.

53. Gomaa A, Hu H, Bellinger D, Schwartz J, Tsaih SW, Gonzalez-Cossio T, et al. Maternal bone lead as an independent risk factor for fetal neurotoxicity: a prospective study. Pediatrics 2002;110(1 Pt 1):110-8.

54. Tellez-Rojo MM, Hernandez-Avila M, Gonzalez-Cossio T, Romieu I, Aro A Palazuelos E, et al. Impact of breastfeeding on the mobilization of lead from bone. Am J Epidemiol 2002;155(5):420-8.

55. Lanocha N, Kalisinska E, Kosik-Bogacka DI, Budis H, Sokolowski S, Bohatyrewicz A, et al. The effect of environmental factors on concentration of trace elements in hip joint bones of patients after hip replacement surgery. Ann Agric Environ Med 2013;20(3):487-93. 